\title{
Musical Times
}

Diversity of Key in the Church Service

Author(s): Edward Young

Source: The Musical Times and Singing Class Circular, Vol. 16, No. 384 (Feb. 1, 1875), pp. 786787

Published by: Musical Times Publications Ltd.

Stable URL: http://www.jstor.org/stable/3355174

Accessed: 05/02/2015 03:08

Your use of the JSTOR archive indicates your acceptance of the Terms \& Conditions of Use, available at http://www.jstor.org/page/info/about/policies/terms.jsp

JSTOR is a not-for-profit service that helps scholars, researchers, and students discover, use, and build upon a wide range of content in a trusted digital archive. We use information technology and tools to increase productivity and facilitate new forms of scholarship. For more information about JSTOR, please contact support@ jstor.org. 
care to compete for the next Prize, he is at perfect liberty to do so on signifying his intention to the Registrar, Mr. Jennings.

I am, Sir, your obedient servant, H. G. Bonavia Hunt, Warden.

4, Garden Court, Middle Temple, E.C.

\section{THE WAGNER THEORY.}

TO THE EDITOR OF THE MUSICAL TIMES.

SIR,-It is generally observable that the old ladies and the young children-in fact, all those members of every family who are debarred from witnessing the exciting and extraordinary events which happen-are the very ones who have the most to say about them. We, in England, are the corresponding members of the musical family, and while hoping for representations of Richard Wagner's works, which are promised but never given, we faithfully perform the part of the old ladies and young children above mentioned, by indulging in more than our share of talk on the subject. Much of this talk, however, and many tedious arguments, ending in nothing, might have been spared if this new artwork had been pronounced at once what it is, a new art. Thus all those comparisons with other music, which have led to so much confusion and misunderstanding, would have been avoided. This " artwork" or "art," but not "music" of the future is as much poetry as music, and the combination produces something new and distinct from either in its separate form, in the same way as blue and yellow combined produce a new and wholly distinct colour with a character of its own, and not recognisable as a part of either. Each of the arts, as well as each of the colours, has to sacrifice its distinct complexion to make the something new that we so much admire. Green has a real existence-as real as either of the colours of which it is formed: so has the art-work of Wagner, and none the less so because formed of two well-known arts. As there are shades of green according as yellow or blue predominates, so there have always been indistinct approaches to this artwork whenever the two arts have not been kept quite separate; but Wagner has been the first to do consciously what others sometimes did intuitively. This definition shows the fallacy of the objection so often raised, and which sounds at first so plausible, that each of the arts has a separate existence, and all efforts to bring one into the domain of another always have led to the degradation of both, and resulted in partial or utter failure. In proof of this assertion is brought forward Mr. Gibson's attempt to unite sculpture and painting, which, to the artist, led to anything but favourable results. All this, as we have said, sounds at first very convincing, but when we come to reflect, we see that Mr. Gibson's way of setting to work corresponds exactly to the way in which music and poetry are united (?) in the opera as we now have it. The one is music (not music and poetry), the other is sculpture (not sculpture and painting); there is in each case the absolute, unyielding form of the art, and the sister art is only called in to give warmth, colour, and life to that form. Such an unfair partnership, we agree, must result artistically in miserable failure; and the opera, as we now have it, will consequently always hold a secondary place as a work of art, in spite of the delightful strains so often found in it, which we all find pleasure in listening to. Wagner weds the two arts, making each the support essential to the existence of the other. This new artwork is not expected to supersede the opera: this is a notion which has called forth many complaints and given Wagner many enemies. The opera in its present form will continue to hold the place it now does, and Wagner's artwork will no more interfere with its existence than the symphony in its grandest, most sublime power has given the death-blow to the dance tune, from which it sprang.

"Excelsior" is the motto on every artist's banner, and great men always arise when the world is idly sinking into contented repose, vainly dreaming perfection is already attained. They cry, "peace, peace," and even while they are speaking the war-cry "onward" is sounding in the distance: a few-a very few at first-do not resent the call to arouse themselves and gather round the standard, which, to bear triumphantly, they know, if the history of the past teaches anything, they shall have to fight many a hard battle.

VERRING.

\section{NATIONAL MUSIC MEETINGS.}

TO THE EDITOR OF THE MUSICAL TIMES.

SIR,-As there seems to be some misapprehension with reference to the National Music Meetings taking place this year, I shall be obliged if you will allow me thus to in form the musical public that the Third Series of Competitive Performances between Choral Societies, Solo Singers, and Military Bands, will be held at the Crystal Palace, on the Ist, 2nd, $5^{\text {th, }} 6$ th, $7^{\text {th }}$, 8th, and roth of July next ; that Authorised Editions of the Music to be prepared for performance are published by Messrs. Novello and Co., and Messrs. Metzler and Co.; and that Rules, and Forms of Entry, and all other particulars can be obtained on application at my office, or by letter addressed to Mr. Willert Beale, at the Crystal Palace.

I remain,

Your obedient servant,

S. Flood Page, Secretary.

Crystal Palace, S.E., 2 Ist January, I875.

\section{DIVERSITY OF KEY IN THE CHURCH SERVICE.} TO THE EDITOR OF THE MUSICAL TIMES.

SIR,-I have been guilty of an innocent act, and am threatened with the crown of martyrdom in consequence. Can you find me an explanatory corner in your valued columns?

The documentary facts are in a nutshell. You, sir, in a pleasant notice of my Morning Service, observe, "The author opens a novel question . . . the necessity, or even desirability, for all the pieces of a Service to be in one and the same key . . . illustrated in the music under notice, where the first piece is in $E$ flat, the second in A, and the last in E." Again, in a congenial notice of my Evening Service, you say, "The principle enunciated in what we may regard as the earlier portion of the work is here abrogated." And now, in a review of Mr. Barnby's elaborate Service, you say, "This principle of diversifying the tonality in the numbers of a Service, is proposed by the Rev. Edward Young in a Preface . . . and it is well worthy the earnest thought of musicians." On the other hand, we read in another journal that shall be nameless, "With some reason the composer explains that he did not choose to follow the old plan of writing his whole Service in the same key. Now, without saying, $\& c .$, it does appear to us wise to set the different movements in keys having some relationship." Another journal, which for like reason I also refrain from naming, tells us flatly, "The Rev. Edward Young's Morning Service is not altogether a musical satisfaction, inasmuch as the composer does not succeed in his attempt to neglect the rules of art, and so justify his Preface, which has eloquent thoughts. . . . Such a change of tonality, even with the intervening lesson, is neither pleasant; nor likely to secure, at least from non-professional singers, a just intonation." And this, sir, is all a professional critic can say of notes that have thrilled hearts and moistened eyes of gentle and simple, and are congregationally sung-I had almost said, to the ends of the world!

But so-the subject is fairly broached-I am fairly in for a share in it; I may fairly ask leave for an opening word regarding it. I shall content myself with a brace of questions. Ere, however, the scene widens, and I have "greatness thrust upon me," I must whisper-in an "aside" -a little statement of facts.

This diversity of key was not assumed for the assertion of an abstract principle. In nine successive issues the Venite and $\mathrm{Te}$ Deum were in three, and the Jubilate in two flats; the Kyrie having been subsequently added. It happened that, without my cognizance, a copy was shevn to-perhaps I may say-the first Church musician amongst 
us; and that eminent man was not only good enough to propose the adoption of the Service in his own Cathedral, but to suggest my putting it forth in a more condensed, or, as he expressed it, a less "orchestral" form, "for general use in our Cathedrals and choirs." The work of revision once started, I took count of an objection sometimes made to the pitch of the opening treble note $(F)$ in the Jubilate, and, for congregational convenience, lowered the piece a semitone. But then, methought, there is old Red-tape in the back ground! so I made formal protest, in self defence, but with my foot on a great principle, against crotchets.

I come now to my pair of questions: one, of course, musical; but the first, theological. This, Sir, is Church business. The Church is a "house of prayer," and not a concert room; and I a clergyman of some six and forty years standing. I ask then, first, what key relation ship is there-theologically speaking-between the Venite, Te Deum, and Jubilate, or Benedictus? What between these and the first and second Lesson? What between the chanted Psalms amongst themselves $(1,2,3,4$, and 5 to wit)? What between the metrical Psalms or Hymns? Who gave musicians the right to exact noted coherences where there is an absolute incoherence in all, to which Church music should be subordinate? Why should the devotional spirit have eagle's wings, and its musical utterance be tied and bound by cold pedantic empiricisms ? Yes, and why-to quote my own poor words-should one be called to forget a golden rule I am never tired of repeating, "Word and note like husband and wife?" As for "non-professional singers" and "just intonation," one might ask how long shall music be tolerated in the worship of the sanctuary, if men are to hold the sense of a key note through all the absorbing beauties and commanding wonders of a lesson from the Word of God ?

But I must come closer yet, and ask, secondly, where do we find this ignoble slavery to tonic formalism in the unapproachable work of "the mighty master" who stands alone? Where in No. 4 ending in A, and No. 5 opening in $\mathrm{D}$ minor? Where in No. 6 ending in $\mathrm{D}$ minor, and No. 7 opening in G minor? Where in No. 8 ending in A, and No. 9 opening in D? Where in No. II ending in $B$ minor, and No. I2 opening in G? Where in No. 29 ending in B major, and No. 30 opening in $\mathrm{E}$ minor? Or, to cite but one more case, wherein No. 32 ending again in three sharps, and 33 opening in one flat?

There can be but one answer to all these queries; and there is no escape from their inferences. To say that an Oratorio demanded changes were but attempting to avoid the mark. The one undisguisable ruling point is that, between these immortal pieces there is not the slightest figment or key relationship, and this ruling point is the more pointed from the fact that these absolutely unconnected outbursts of religion and musical fervour have absolutely no intervening medium, no second lesson, no hymn, no prayer standing between them, nothing but the needful pause of singer and hearer to take breath and begin again.

There are other questions of no small moment that, in these days of advancing freedom, will rise up, and demand an answer. One is before me now : but I forbear. I only want that common-sense and high-toned feeling should wake up and look about them. Yours, Sir, with all respect,

EDWARD Young.

[We agree fully in the principle here enunciated, and, though contrary to more general practice, can feel no reason for identity of key in the separated pieces of a Church Service, far less in those of the Morning and Evening Services. In Beethoven's Mass in C, the Sanctus is in $\mathrm{A}$; and in his Mass in D, the Credo is in B flat; and what holds good in the Roman Service cannot be musically at fault in the Anglican, while what has the authority of this mighty master must hold good everywhere. The instances quoted by $\mathrm{Mr}$. Young (of course from the Messiah) are all in such closely-related keys that the transition from any one piece to that which follows it has a perfectly satisfactory effect, and induces an agreeable variety; those quoted from Beethoven are in analogous but less closely related keys than Handel's, and being divided from the other portions of the composition by intervening matter with or without music, startle not by their diversity, though they charmingly relieve the monotony, that is to some extent a consequence of a whole Service having one chiefly prevailing key. We only contend, but this more for the sake of conscience than of effect, that it is preferable for the several numbers of one composition to have some tonal affinity, to their being in various keys that have either the remotest relationship or no relationship at all. The nicest of ears are unshocked by the tonal diversity of the several pieces in an opera which are separated by speaking; where separated by recitative, the modulations in this lead satisfactorily from the key of one piece to that of another, which is not always the case with the chanting and intoning in a Service; and what is musically agreeable in a theatre cannot be offensive in a Church.

The Writer of the Article.]

\section{TO CORRESPONDENTS.}

* Notices of concerts, and other information supplied by our friends in the country, must be forwarded as early as possible after the occurrence; otherwise they cannot be inserted. Our correspondents must specifically denote the date of each concert, for without such date no notice can be taken of the performance.

Our correspondents will greatly oblige by writing all names as clearly as possible, as we cannot be responsible for any mistakes that may occur.

Correspondents are informed that their names and addresses must accompany all communications.

We cannot undertake to return offered contributions; the authors therefore, will do well to retain copies.

Notice is sent to all Subscribers whose payment (in advance) is ex hausted. The paper will be discontinued where the Subscription is not renewed. We again remind those who are disappointed in obtaining back numbers that, although the music pages are always stereotyped, only a sufficient quantity of the rest of the paper $i$ printed to supply the current sale.

F. E. Penna.-The subject of your letter has already been decided by the majority of the pointed Psalters now in use.

JoHN BELL. - If our correspondent will state temperately what he has to say, we will give insertion to his letter.

Musrque.-It is quite out of our province to answer the questions of our correspondent.

T. Vincent. - We cannot re-open the correspondence respecting the "doubled air."

D. BritTAin.-Consult any singing-master in whom you have confidence.

\section{BRIEF SUMMARY OF COUNTRY NEWS.}

\section{We do not hold ourselves responsible for any opinions expressed $i$} this Summary; as all the notices are either collated from the loca papers, or supplied to us by occasional correspondents. ASHTON-UPON-MERSEY, NEAR MANCHESTER.-On the 20th ult. a
concert was given in aid of the parochial school funds. The choruses, Mr. N. Dumville (of Mancliester Cathedral), and Mr. Smith. Mrs. Mr. N. Dumville (of Manchester
Ellis contributed pianoforte solos.

BAтн.-Mr. Simms's concert took place on Saturday evening the 9 th ult., in the Assembly Rooms. The programme was an attractive one, consisting almost entirely of operatic music, the first part being devoted exclusively to Balfe's Il Talismano. The rose song, "Flowre 1 kiss thee," was artistically given by Signor Urio, and Madame Campobello-Sinico was warmly received in the two arias, "Edith" prayer " and "Radiant splendour." Madame Stella-Bonheur an Signor Campobello were the other vocalists. Signor Tito Mattei gave as a pianoforte solo a fantasia, of his own arrangement, on the English accompanist.

BATLEY.-The twenty-second concert of the Choral Society was given in the Town Hall on Monday evening the IIth ult., the work being Haydn's Creation. The vocalists were Miss Clelland (soprano) Mr. H. Thompson (tenor), and Mr. Rickard (bass). Miss Clelland sang with good taste and expression, and was warmly applauded at the conclusion of the airs "With verdure clad "and "On mighty pens." Mr. H. Thompson, in the recit. "And God created man," and air "In native worth," gave proof of the possession of a fair voice, the upper notes being particularly good. Vetter led the band, and Mr. J. W. Bowling conducted. The chorus, (which led the band, and $\mathrm{Mr}$. W (which was augmented by members of the Harmonic Society, Morley) under the conductorship of Mr. Bowling, was full and efiective. A ment to the recitatives and airs (especially "In native worth") was excellent. 